\title{
Cannabis therapy in neurological disorders: Recent advances and perspectives
}

\author{
Alexandru MANDICl${ }^{1}$, Daniel COJOCARIU², Anca MIRON ${ }^{1}$ \\ ${ }^{1}$ Department of Pharmacognosy, Faculty of Pharmacy, \\ "Gr.T. Popa" University of Medicine and Pharmacy, lasi, Romania \\ 2Intensive Care Unit, "Sf. Spiridon" Clinical Emergency County Hospital, Iasi, Romania
}

\begin{abstract}
Both phytocannabinoids (49-tetrahydrocannabinol, cannabidiol) and synthetic derivatives (nabilone, dronabinol) showed therapeutic benefits in some neurological disorders. Cannabis inhalation was reported to attenuate several symptoms (rigidity, bradykinesia, tremor) in Parkinson's disease. A significant reduction in monthly seizures in patients with epilepsy has been noted for cannabidiol, while administration of $\Delta 9$-tetrahydrocannabinol resulted in benefits on psychomotor agitation in patients suffering from Alzheimer's disease. Although there are clinical studies supporting the use of cannabis preparations as adjuvant therapy in neurological disorders, more investigations are needed to assess their safety and efficacy.
\end{abstract}

Keywords: cannabis, phytocannabinoids, neurologic disorders

\section{INTRODUCTION}

Since ancient times, Cannabis sativa L. (Cannabaceae, hemp) has been used for its medicinal benefits.

Reduction in nausea, vomiting, orexigenic effects in patients with AIDS or patients receiving chemotherapy, reduction of intraocular pressure, as well as general analgesic effects are among its known pharmacological effects (1-5). Cannabis sativa is indigenous to Central Asia being cultivated both legally for fibers and seeds, and illicitly for the production of illegal drugs such as marijuana (dried flower buds from female plants), hashish (compressed plant trichomes) and oils (rich in cannabidiol, but containing less than $0.2 \%$ tetrahydrocannabinol). The most potent phytocannabinoids are $\Delta 9$-tetrahydrocannabinol (THC) and cannabidiol (CBD). Also, two synthetic THC derivatives, nabilone and dronabinol, are used for medical purposes. THC is responsible for the psychoactive, undesirable effects whereas $\mathrm{CBD}$, as well as nabilone and dronabinol, lack such effects (6).

The endogenous cannabinoid system was discovered in 1990. Since then, extensive research on the potential use of cannabinoids in neurodegenerative disorders has been done. Endocannabinoids activate the cannabinoid receptors (G-protein-coupled receptors) resulting in an inhibitory effect on glutamate release (7).

The cannabinoid receptors, namely CB1 (cannabinoid receptor type 1) and CB2 (cannabinoid receptor type 2 ), are present in the nervous and immune systems. Most of $C B 1$ receptors are located in areas of pain signalling control in central nervous system (CNS), and, to a lesser extent, in the cerebellum and hippocampus, basal ganglia, neuromuscular junctions and peripheral nerves (8). Activation of $\mathrm{CB} 1$ receptors 
results in the inhibition of glutamate and gammaaminobutyric acid (GABA) release from the presynaptic terminals, with subsequent influence on memory processing, nociceptive pathways, psychoactivity and motor control. CB1 receptor activation explains the benefits (reduced nausea and vomiting, pain alleviation, enhanced appetite, reduced dyskinezia and intraocular pressure) but also the side effects (somnolence, fatigue, possible hallucinations) reported by patients. CB2 receptor activation leads to attenuation of chronic inflammation and supression of chronic pain, but the complete mechanism underlying the aforementioned effects is yet to be understood. $\mathrm{CB} 2$ receptors are present in peripheral nerves, brain microglia, keratinocytes, bone and liver. CB2, and to a lesser extent $\mathrm{CB} 1$ receptors, are also found in macrophages, polymorphonuclear neutrophils and lymphocytes, their activation supporting, in part, the anti-inflammatory potential of cannabinoids (8).

The endocannabinoid system is involved in tissue homeostasis after pathological alterations, thus being a potential therapeutic target in numerous diseases, including neurological ones. Animal studies showed alterations in the endocannabinoid system in different neurological disorders and efforts have been made to use these findings for the development of new treatments. These efforts made possible the approval of nabiximols (Sativex ${ }^{\circledR}$, a mixture of THC and CBD, each spray of $0.1 \mathrm{ml}$ containing $2.7 \mathrm{mg}$ THC and $2.5 \mathrm{mg}$ CBD) for the treatment of pain and/or spasticity in multiple sclerosis in 2005 in U.S.A. and Canada, which was a milestone in cannabis research (9).

A systematic review done by the American Academy of Neurology, evaluating publications from 1948 to 2013 regarding cannabinoids use in multiple sclerosis, motor diseases, and epilepsy, revealed that only THC in combination with CBD or CBD alone (oral administration) seemed to alleviate spasticity in multiple sclerosis (10). Other formulations seemed to be effective against the aforementioned disorders, but with less evidence. Proof was insufficient to conclude on the efficacy of smoked cannabis. There was no conclusive evidence regarding the effectiveness of cannabis and cannabis-derived products in other neurological disorders, such as Huntington's disease and Tourette syndrome (11).

\section{PARKINSON'S DISEASE}

In 1888, Gowers noticed some benefits for "Indian hemp" in a patient with Parkinson's disease (12).
As the cannabinoid receptors have a high density in basal ganglia, the potential benefits of cannabinoids in Parkinson's disease were extensively investigated, but with inconclusive results. Most studies reported high levels of endocannabinoids in patients with Parkinson's disease. However, levodopa was found to decrease these higher levels of endocannabinoids in the cerebrospinal fluid of affected patients (13). In the lipopolysaccharide and oxidopamine treated rats, THC, CBD and $\triangle 9$-tetrahydrocannabivarin (THCV) showed antiparkinsonian effects. The benefits were ascribed to the antioxidant effects of THC and CBD whereas, in case of THCV, CB2 agonism and CB1 antagonism were evoked (14).

Several clinical trials analyzed cannabinoids effects on dyskinesias in Parkinson's disease patients, but with inconclusive results. One randomized, double-blind, placebo-controlled, crossover trial in seven patients found nabilone (synthetic cannabinoid agonist on both CB1 and CB2 receptors) to induce a drastic reduction in dyskinesias (15). Lotan et al. (2014) reported that cannabis smoking has beneficial effects on tremor, rigidity, and bradykinesia, causing only a very small improvement in patients posture $(16,17)$. In a double-blind study evaluating CBD benefits in patients suffering from Parkinson's disease, Chagas et al. (2014) found that improvement in life quality was noted at the highest dose tested ( $300 \mathrm{mg}$ of CBD daily for six weeks) (18). A survey done by Venderová et al. (2004) on 339 Czech patients receiving fresh or dried cannabis leaves (half a teaspoon daily) outlined a significant alleviation of symptoms after aproximately 1.7 months after first cannabis use. Although subjective, authors noted improvements in rigidity, bradykinesia, resting tremor, and general function (19).

\section{HUNTINGTON'S DISEASE}

Huntington's disease affects the dopaminergic neurons in globus pallidus with consequent locomotor, mood and/or mental impairments. Pharmacological interventions in the endocannabinoid metabolism protected neurons in different models of Huntington's disease. Endocannabinoid reuptake inhibitors had anti-hyperkinetic effects in animals treated with 3-nitropropionic acid, mostly via activation of TRPV1 (transient receptor potential cation channel subfamily $\checkmark$ member 1 , a capsaicin-like receptor, also activated by endocannabinoids in pain sensation) (20). 
One double-blind, randomized, controlled study assessed the effects of CBD $(10 \mathrm{mg} / \mathrm{kg} /$ day, oral administration for six weeks) in patients with Huntington's disease. No clinically significant improvements were observed in chorea sensitivity, functional ability or information recall in comparison with placebo (21). The latter findings were confirmed by a double-blind, placebo-controlled, randomized, crossover, pilot study initiated by Lopez-Sendon Moreno et al. (2016) on 26 patients with Huntington's disease. The study investigated the potential benefits of nabiximols and revealed that while nabiximols $\left(\right.$ Sativex ${ }^{\oplus}$ ) were well tolerated, they did not improve the clinical outcomes (22).

\section{MULTIPLE SCLEROSIS}

Spasticity is the main cause of disability in patients with multiple sclerosis. Cannabinoids reduce glutamate release, thereby regulating glutamatergic excitability and consequently spasticity (23). In mice models with autoimmune encephalomyelitis which recreates multiple sclerosis in humans, CBD seemed to ameliorate disease symptoms. The mechanisms underlying the reduction in spasticity are the decrease in pro-inflammatory mediators and activation of PPAR $\gamma$ (peroxisome proliferator-activated receptor gamma, also known as glitazone receptor) and PI3K-AKT-mTOR pathway (regulator of cell cycle) (24).

The MUSEC trial (2012), a double-blind, placebocontrolled, phase III study, involving 279 patients, assessed the effects of oral administration of a standardized Cannabis sativa extract (0.8-1.8 mg CBD and $2.5 \mathrm{mg}$ THC) on spasticity, pain, but also sleep quality in multiple sclerosis. The study revealed the capacity of Cannabis sativa standardized extract to alleviate muscle stiffness in multiple sclerosis. Authors also concluded that there was an effective pain remission in patients, especially in patients having high baseline pain score (25). In a randomized, placebo-controlled, crossover trial, Corey-Bloom et al. (2012) showed that inhaled cannabis reduced the treatment-resistant spasticity in mutiple sclerosis (26). A placebo-controlled, double-blind, betweengroups study on 493 patients with progressive multiple sclerosis, did not find any effect on disease progression when receiving a daily oral cannabis extract (standardized in 0.8-1.8 $\mathrm{mg}$ CBD and 2.5 $\mathrm{mg}$ THC), dose-adjusted for each patient to a maximum of $28 \mathrm{mg}$ of THC daily for ten weeks (27). As noted elsewhere, $40-60 \%$ of individuals with multiple sclerosis manifest some degree of cognitive dysfunction, therefore the use of cannabis products may further compromise cognitive functions (28).

\section{AMYOTROPHIC LATERAL SCLEROSIS}

The main symptoms of amyotrophic lateral sclerosis are miastenia, spasticity, and respiratory difficulties. The disease is fatal and affects the upper and lower motor neurons originating in the motor cortex in brain and spinal cord, respectively. Cannabinoids are supposed to act in the aforementioned regions, thus being potentially useful in alleviating symptoms such as spasticity, dysphagia, negative mood and pain (29). As the immune cells express CB2 receptors, cannabis might play a role in downregulating cytokine and chemokine production, hence reducing neuroinflammation associated with amyotrophic lateral sclerosis pathogenesis. Additionally, cannabis may provide neuroprotection by modulating glutamatergic transmission (30).

Currently there is a lack of clinical data to support cannabinoids use in amyotrophic lateral sclerosis. However, there is only one randomized, double-blind, placebo-controlled, crossover trial that investigated the benefits of dronabinol in 27 patients. It has been noted that even though $5 \mathrm{mg}$ of dronabinol is well-tolerated, there was no alleviation in the number or intensity of cramps, quality of life, appetite, sleep, or mood (31).

\section{EPILEPSY AND SEIZURES}

Epilepsy affects 50.4 per 100,000 people per year, being one of the most frequent neurological disorders. Approximately $30 \%$ of the patients with epilepsy have a drug-resistant form, that is failure to control one's seizures with the adjusted dose of at least two antiepileptic drugs (32). CBD showed anticonvulsant effects in the pentylenetetrazole-induced epilepsy model, pilocarpine temporal lobe epilepsy model and penicillin-induced partial seizure model most probably via G-protein-coupled receptor 55 (GPR55) antagonism and TRPV1 desensitization (33).

Only two randomized, placebo-controlled studies done by Devinsky et al. $(2016,2017)$, evaluated the potential benefits of CBD as adjuvant therapy in epilepsy. In the 2016 study, Devinsky et al. evaluated the efficacy of CBD (2-5 mg/kg/day for 12 weeks) as an add-on therapy to the classical treatment (antiepileptic drugs) on 137 patients with Dravet and Lennox-Gastaut syndromes, which are severe forms of epilepsy. Authors noted a reduction in monthly 
seizures frequency in $36.5 \%$ of patients, with the most significant reduction in patients with focal and atonic seizures (34). In 2017, Devinsky et al. performed a double-blind, randomized clinical study on 120 patients (both children and adults) suffering from Dravet syndrome and drug-resistant epilepsy, split into two groups, control and placebo. The control group received $20 \mathrm{mg} / \mathrm{kg} /$ day CBD for 14 weeks as adjuvant therapy. $43 \%$ of patients in the control group had more than $50 \%$ reduction in seizures frequency. Also, in the control group, $5 \%$ of patients had no seizures (35).

\section{ALZHEIMER'S DISEASE}

Tau proteins, essential for microtubule assembly, integrity of cytoskeleton and signal transport in neurons, are the main protagonists in this disease, developing fibrillary tangles. In a model of Alzheimer's disease-related neuroinflammation (intrahippocampal injection of the human amyloid- $\beta$ in mice), CB1 agonists showed promising effects against neuronal tau hyperphosphorylation and behavioral impairments (36). Additionally, cannabinoids inhibit acetylcholinesterase and $\beta$ amyloid aggregation, while agonism on CB1 and 2 receptors results in a significant increase of $\beta$ amyloid clearance across the blood-brain barrier (37-39).

Casajeros et al. (2013) noted that nabiximols reduced tangling of tau proteins in mice, improving dopamine metabolism, glial function and oxidative stress, as well as reduction in anxiety and self-injury (40).

In 2006, Walther et al. initiated an open-label, twoweek study, on five Alzheimer's disease patients and one patient with vascular dementia. Patients presented improvements in the nocturnal motor activity, hunger, agitation, and irritability with no adverse events when receiving $2.5 \mathrm{mg}$ THC at 19:00 h, on a daily basis (41). However, a randomized, controlled trial conducted by van den Elsen et al. (2015) on 50 patients with dementia receiving 1.5 mg THC (three times a day, for three weeks), failed to show any benefit in comparison with placebo. Auhors also noted that a total absence of adverse reactions might be due to inadequate dosage regimens (42).

\section{NEUROPATHIC PAIN}

Cannabis has been used to alleviate pain since 2900

b.C., as mentioned in ancient Chinese texts. The cause of neuropathic pain are inadequate messages sent to pain centers by damaged spinal and/or sensory nerves. In diabetic patients with neuropathy, for example, pain sensation is not in the foot tissue per se, being localized in the peripheral nociceptors. As the disease affects them, the brain misinterprets the incoming signals as pain in the affected tissues.

Cannabis plants per se are rarely used as painkiller medicine, patients using instead NSAIDs, GABA agonists (gabapentin, pregabalin) and opioids $(43,44)$.

When damage is inflicted, all cells synthesize anandamide (an endogenous cannabinoid derived from arachidonic acid) which modulates pain signals transmission by $\mathrm{CB}$ receptors agonism, in turn leading to a reduced inflammation and sensitization. THC also acts as an agonist on $\mathrm{CB}$ receptors. $\mathrm{CB} 1$ receptors control the release of neurotransmitters in CNS; they are present in sensory neurons of the dorsal basal ganglia and trigeminal ganglion. To a lesser extent, CB2 receptors are found in CNS and dorsal basal ganglia, being up-regulated in response to peripheral nerve injuries. They modulate neuronal and immune interactions and inflammatory hyperalgesia (43).

A recent systematic review and meta-analysis examined 28 randomized trials involving 2,454 patients with chronic pain and noted that administration of cannabinoids was associated with a greater reduction in pain compared with placebo $37 \%$ vs. $31 \%)$. According to Whiting et al. (2015), moderate evidence emerged in supporting cannabinoids use in the chronic pain treatment, especially in the neuropathic pain (45). A placebo-controlled trial (not included in Whiting's meta-analysis), using aerosolized cannabis, showed attenuation of the conventional analgesics-resistant pain in patients with diabetic neuropathy; the analgesic effect was dose-dependent (46). The randomized, placebo-controlled, crossover study of Wilsey et al. (2013), involving 39 partients with central neuropathic pain (related to spinal cord damage and disease) using vaporized cannabis, showed dose-independently reductions in neuropathic pain scale ratings (47). Literature examination showed no conclusive studies regarding cannabis benefits in different headache disorders, though it appears that cannabis may emerge as a potential treatment.

\section{SAFETY}

The use of cannabis is subjected to concerns regarding THC and CBD concentrations, as they might vary with species and extraction methods. In addition, common adverse reactions similar to other CNS depressants (barbiturates, benzodiazepines, neuroleptic medication) might occur. 
TABLE 1. SUmmary of clinical trials involving cannabis, phytocannabinoids and synthetic cannabinoids

\begin{tabular}{|c|c|c|c|c|c|c|}
\hline $\begin{array}{c}\text { Neurological } \\
\text { disorder }\end{array}$ & Type of study & Patients & Treatment & Study medication & Outcome & Reference \\
\hline \multirow[t]{3}{*}{$\begin{array}{l}\text { Parkinson's } \\
\text { disease }\end{array}$} & survey & 339 & Yes & oral cannabis leaves & $\begin{array}{c}\text { improvement in cardinal } \\
\text { motor symptoms and } \\
\text { dyskinezia }\end{array}$ & $\begin{array}{l}\text { Venderova et al. } \\
\text { (2004) }\end{array}$ \\
\hline & $\begin{array}{l}\text { placebo-controlled, } \\
\text { double-blind trial }\end{array}$ & 21 & & $\begin{array}{l}75 \text { to } 300 \mathrm{mg} \text { CBD, } 6 \\
\text { weeks }\end{array}$ & $\begin{array}{l}\text { no effectcs on motor } \\
\text { functioning }\end{array}$ & $\begin{array}{l}\text { Chagas et al. } \\
\text { (2014) }\end{array}$ \\
\hline & $\begin{array}{l}\text { open-label } \\
\text { observational }\end{array}$ & 22 & No & inhaled cannabis & $\begin{array}{c}\text { reduced effect on } \\
\text { bradykinesia } \\
\text { small improvement } \\
\text { in tremor, rigidity and } \\
\text { posture }\end{array}$ & $\begin{array}{l}\text { Lotan et al. } \\
\qquad(2014)\end{array}$ \\
\hline \multirow[t]{2}{*}{$\begin{array}{l}\text { Huntington's } \\
\text { disease }\end{array}$} & $\begin{array}{l}\text { double-blind, crossover, } \\
\text { randomized, controlled } \\
\text { trial }\end{array}$ & 15 & No & $\begin{array}{l}10 \mathrm{mg} / \mathrm{kg} / \text { day CBD for } \\
6 \text { weeks }\end{array}$ & \multirow{2}{*}{$\begin{array}{l}\text { no improvements in } \\
\text { disease symptoms }\end{array}$} & $\begin{array}{l}\text { Consroe et al. } \\
\qquad(1991)\end{array}$ \\
\hline & $\begin{array}{l}\text { double-blind, placebo- } \\
\text { controlled, randomized, } \\
\text { crossover, pilot trial }\end{array}$ & 24 & Yes & $\begin{array}{l}\text { Nabiximols }\left(\text { Sativex }{ }^{\circledR} \text { ) }\right. \\
\text { oral spray, } 12 \text { sprays/ } \\
\text { day for } 12 \text { weeks }\end{array}$ & & $\begin{array}{l}\text { Lopez-Sendon } \\
\text { Moreno et al. } \\
\quad(2016)\end{array}$ \\
\hline \multirow[t]{2}{*}{ Alzeheimer's } & open-label, pilot & 5 & - & $\begin{array}{l}2.5 \mathrm{mg} \text { Dronabinol (THC) } \\
\text { daily for } 2 \text { weeks }\end{array}$ & $\begin{array}{c}\text { improvement in } \\
\text { nocturnal motor activity, } \\
\text { agitation, appetite, and } \\
\text { irritability }\end{array}$ & $\begin{array}{l}\text { Walther et al. } \\
\qquad(2006)\end{array}$ \\
\hline & $\begin{array}{l}\text { randomized, double- } \\
\text { blind, placebo } \\
\text { controlled-trial }\end{array}$ & 50 & Yes & $\begin{array}{l}1.5 \mathrm{mg} \text { THC thrice a day } \\
\text { for } 3 \text { weeks }\end{array}$ & $\begin{array}{c}\text { no significant } \\
\text { improvements in NPS* } \\
\text { score, agitation and } \\
\text { quality of life }\end{array}$ & $\begin{array}{l}\text { van den Elsen } \\
\text { et al. } \\
(2015)\end{array}$ \\
\hline \multirow[t]{3}{*}{$\begin{array}{l}\text { Multiple } \\
\text { sclerosis }\end{array}$} & $\begin{array}{l}\text { double-blind, } \\
\text { placebo controlled }\end{array}$ & 279 & Yes/No & $\begin{array}{l}\text { oral cannabis extract } \\
\text { (max. } 25 \mathrm{mg} \text { THC daily } \\
\text { dor } 10 \text { weeks) }\end{array}$ & $\begin{array}{l}\text { significant reduction in } \\
\text { muscle stiffness }\end{array}$ & $\begin{array}{l}\text { Zajicek et al. } \\
\qquad(2012)\end{array}$ \\
\hline & $\begin{array}{l}\text { placebo controlled, } \\
\text { double-blind crossover } \\
\text { study }\end{array}$ & 30 & No & $\begin{array}{l}\text { smoked cannabis } \\
(4 \% \mathrm{THC}) \text { for } 3 \text { days }\end{array}$ & $\begin{array}{l}\text { significant reduction in } \\
\text { spasticity and pain }\end{array}$ & $\begin{array}{l}\text { Corey-Bloom et } \\
\text { al. (2012) }\end{array}$ \\
\hline & $\begin{array}{l}\text { placebo-controlled, } \\
\text { double-blind, between- } \\
\text { groups }\end{array}$ & 493 & Yes & $\begin{array}{l}\text { oral THC (dose-adjusted, } \\
\text { max } 28 \text { mg daily) for } 36 \\
\text { months }\end{array}$ & $\begin{array}{c}\text { no overall treatment } \\
\text { effect on clinical disease } \\
\text { progression }\end{array}$ & $\begin{array}{l}\text { Zajicek et al. } \\
\qquad(2013)\end{array}$ \\
\hline $\begin{array}{l}\text { Amyotrophic } \\
\text { lateral } \\
\text { disease }\end{array}$ & $\begin{array}{l}\text { srandomized, double- } \\
\text { blind, placebo con- } \\
\text { trolled, crossover trial }\end{array}$ & 27 & No & $\begin{array}{l}5 \mathrm{mg} \text { THC twice a day for } \\
2 \text { weeks }\end{array}$ & $\begin{array}{c}\text { no significant } \\
\text { improvement in cramp } \\
\text { intensity }\end{array}$ & $\begin{array}{l}\text { Weber et al. } \\
\qquad(2010)\end{array}$ \\
\hline \multirow[t]{2}{*}{ Epilepsy } & open-label trial & 214 & Yes & $\begin{array}{l}2-5 \mathrm{mg} / \mathrm{kg} / \text { day oral CBD } \\
\text { for } 12 \text { weeks }\end{array}$ & $\begin{array}{l}\text { possible reduction of } \\
\text { seizures frequency }\end{array}$ & $\begin{array}{c}\text { Devinsky et al. } \\
\text { (2016) }\end{array}$ \\
\hline & $\begin{array}{l}\text { double-blind, } \\
\text { placebo-controlled } \\
\text { trial }\end{array}$ & 120 & Yes & $\begin{array}{l}20 \mathrm{mg} / \mathrm{kg} \text { oral CBD for } 14 \\
\text { weeks }\end{array}$ & $\begin{array}{c}\text { reduction in convulsive- } \\
\text { seizure frequency; } \\
\text { higher rates of adverse } \\
\text { events }\end{array}$ & $\begin{array}{l}\text { Devinsky et al. } \\
\text { (2017) }\end{array}$ \\
\hline \multirow[t]{3}{*}{$\begin{array}{c}\text { Neuropathic } \\
\text { pain }\end{array}$} & $\begin{array}{l}\text { placebo-controlled, } \\
\text { double-blind, crossover } \\
\text { study }\end{array}$ & 39 & - & $\begin{array}{l}\text { inhaled, cannabis } \\
(1.29 \% / 3.53 \% \text { THC) }\end{array}$ & $\begin{array}{c}\text { reduction in pain; } \\
\text { dose-independent } \\
\text { efficacy }\end{array}$ & $\begin{array}{l}\text { Wilsey et al. } \\
\qquad(2013)\end{array}$ \\
\hline & $\begin{array}{l}\text { placebo-controlled, } \\
\text { double-blind, between } \\
\text { groups trial }\end{array}$ & 246 & Yes & $\begin{array}{l}\text { sublingual, nabiximols } \\
\left(\text { Sativex }{ }^{\circledast}\right) 24 \text { sprays/day } \\
\text { for } 14 \text { weeks }\end{array}$ & $\begin{array}{c}\text { significant } \\
\text { improvements in pain } \\
\text { and sleep quality }\end{array}$ & $\begin{array}{l}\text { Serpell et al. } \\
\qquad(2014)\end{array}$ \\
\hline & meta-analysis & $\begin{array}{c}6462(79 \\
\text { trials })\end{array}$ & Yes/No & $\begin{array}{l}\text { different formulations of } \\
\text { cannabis or derivatives }\end{array}$ & $\begin{array}{c}\text { benefits associated } \\
\text { with cannabinoids } \\
\text { but without statistical } \\
\text { significance }\end{array}$ & $\begin{array}{l}\text { Whiting et al. } \\
\qquad(2015)\end{array}$ \\
\hline
\end{tabular}

*NPS - neuro-psychiatric symptoms

While some evidence suggests that there may be a small reduction in the hippocampal volume in cannabis users vs. non-users, but with no clinical manifestations, other data show that chronic, heavy use of smoked cannabis is associated with a decline in some cognitive abilities (decision-making and conceptual planning) $(48,49)$. 
Unlike THC, CBD seems to have little influence on vital signs such as blood pressure and respiratory function. However, as Devinsky et al. (2017) noted, patients with Dravet syndrome treated with CBD reported significant adverse events such as somnolence (36\%), diarrhea (31\%), fatigue (20\%), vomiting (15\%), fever (15\%), lethargy (13\%) (35). Another potential concern regarding $C B D$ use in different neurological disorders is drug-drug interactions, as CBD may inhibit several CYP450 enzymes (CYP2C9, CYP2D6), in turn leading to a delay in the metabolism of common OTC and prescription drugs that are metabolized by the aforementioned enzymes (50).

\section{CONCLUSIONS}

Although some clinical studies underline beneficial effects of cannabis formulations as an adjuvant therapy in different neurological disorders, research in this field is in its beginnings. Therefore, more studies should be performed to draw a solid conclusion regarding any medical therapy.

More research is needed to answer important questions regarding the safety profiles of either cannabis plant or its different pharmaceutical formulations and potential medical indications, especially in neurological diseases such as amyotrophic lateral sclerosis, multiple sclerosis, epilepsy and Alzheimer's disease.

\section{Author contributions}

Alexandru Mandici - conceptualization, original draft preparation; Daniel Cojocariu - collection of data; Anca Miron - conceptualization, supervision, review, editing.

Conflict of interest: none declared Financial support: none declared

\section{REFERENCES}

1. Walker J, Huang S. Cannabinoid analgesia. Pharmacol Ther. 2002;95:127-135.

2. Kumar RN, Chambers WA, Perthwee RG. Pharmacological actions and therapeutic uses of cannabis and cannabinoids. Anestesia 2001;56:1059-1068.

3. Baker D, Pryce G, Croxford JL et al. Cannabinoids control spasticity and tremor in a multiple sclerosis model. Nature 2002;404:84-87.

4. Martin RS, Luong LA, Welsh NJ et al. Effects of cannabinoid receptor agonists on neuronally-evoked contractions of urinary bladder tissues isolated from rat, mouse, pig dog, monkey and human. Br J Pharmacol. 2000;129:1707-1715.

5. Jarvinen $T$, Pate $D$, Laine K. Cannabinoids in the treatment of glaucoma. Pharmacol Ther. 2002;95:203-220.

6. Ingram G, Pearson OR. Cannabis and multiple sclerosis. Pract Neurol. 2019;19:310-315.

7. Scotter EL, Abood ME, Glass M. The endocannabinoid system as a target for the treatment of neurodegenerative disease. $\mathrm{Br} J$ Pharmacol. 2010;160:480-498.

8. Howlett AC, Barth F, Bonner TI et al. International Union of Pharmacology XXVII classification of cannabinoid receptors. Pharmacol Rev. 2002;54:161-202.

9. Cristino L, Bisogno T, Dimarzo V. Cannabinoids and the expanded andocannabinoid system in neurological disorders. Nature Neurol. 2020;16:9-29.

10. Koppel B, Brust J, Fife T et al. Systematic review: Efficacy and safety of medical marijuana in selected neurologic disorders: Report of the guideline development subcommitte of the American Academy of Neurology. Neurol. 2014;82:1556-1563.

11. Lafaye G, Karila L, Blecha L, Benyamina A. Cannabis, cannabinoids and health. Dial Clin Neurosci. 2017;17:309-317.

12. Gowers WR. A manual of diseases of the nervous system, Philadephia, 1888.

13. Pisani A et al. High endogenous cannabinoid levels in the cerebrospinal fluid of untreated Parkinson's disease patients. Ann Neurol. 2005;57:777-779.

14. Garcia $\mathrm{C}$ et al. Symptom-relieving and neuroprotective effects of the phytocannabinoid delta-(9)-THC in animal models of Parkinson's disease. Br J Pharmacol. 2011;163:1495-1506.
15. Sieradzan KA, Fox SH, Hill M et al. Cannabinoids reduce levodopa induced dyskinezia in Parkinson's disease: a pilot study. Neurology 2001;57:2108-2111.

16. Frankel JP, Hughes A, Lees AJ et al. Marijuana for Parkinsonian tremor. J Neurol Neurosurg Psychiatry. 1990;53:436.

17. Lotan I, Treves T.A, Roditi Y, Djaldetti R. Cannabis (medical marijuana) treatment for motor and non-motor symptoms of Parkinson's disease: an open-label observational study. Clin Neuropharmacol. 2014;37:41-44.

18. Chagas MH et al. Effects of cannabidiol in the treatment of patients with Parkinson's disease: An exploratory double-blind trial. $J$ Phsycopharmacol. 2014;28:1088-1098.

19. Venderová K, Ruzika E, Vorisek V, Visnovsky P. Survey on cannabis use in Parkinson's disease: subjective improvement of motor symptoms. Mov Dis. 2004;19:1102-1106.

20. Lastres-Becker I et al. Compounds acting at the endocannabinoid and/or endovanilloid systems reduce hyperkinesia in a rat model of Huntington's disease. J Neurochem. 2003;84:1097-1109.

21. Consroe P, Laguna J, Allender J et al. Controlled clinical trial of cannabidiol in Huntington's disease. Pharmacol Biochem Behav. 1991;40:701-708.

22. Lopez-Sendon Moreno JL et al. A double-blind randomized, crossover, placebo-controlled, pilot trial with Sativex in Huntington's disease. J Neurol. 2016;263:1390-1400.

23. Baker D, Pryce G, Jackson SJ et al. The biology that underpins the therapeutic potential of cannabis-based medicines for the control of spasticity in multiple sclerosis. Mult Scler Relat Disord. 2012;1:64-75

24. Giacoppo S, Bramanti P, Mazzon E. Sativex in the management of multiple sclerosis-related spasticity: an overview of the last decade of clinical evaluation. Mult Scler Relat Disord. 2017;17:2231.

25. Zajicek J.P, Hobart JC, Slade A et al. Multiple Sclerosis and Extract of Cannabis: results of the MUSEC trial. J Neurol Neurosurg Psychiatry. 2012;83:1125-1132.

26. Corey-Bloom J, Wolfson T, Gamst A et al. Smoked cannabis for spasticity in multiple sclerosis: a randomized, placebo-controlled trial. CMAJ. 2012;184:1143-1150. 
27. Zajicek J, Ball S, Wright D, Vickery J, Nunn A, Miller D, Cano MG, McManus D, Mallik S, Hobart J; CUPID investigator group. Effect of dronabinol on progression in progressive multiple sclerosis (CUPID): a randomised, placebo-controlled trial. Lancet Neurol. 2013;12(9):857-865.

28. Rao SM, Leo GJ, Bernardin L et al. Cognitive disfunction in multiple-sclerosis. I. Frequency, patterns and prediction. Neurol. 1991;41:685-691.

29. Carter GT, Rosen BS. Marijuana in the management of amyotrophic lateral sclerosis. Am J Hosp Palliat Care. 2001;18:264-270.

30. Benbadis SR, Sanchez-Ramos J, Bozorg A et al. Medical marijuana in neurology. Expert Rev Neurother. 2014;14:1453-1456.

31. Weber M, Goldman B, Truniger S. Tetrahydrocannabinol (THC) for cramps in amyotropic lateral sclerosis: a randomized, doubleblind, crossover trial. J Neurol Neurosurg Psychiatry. 2010;81:1135-1140.

32. Ngugi AK, Kaiuki SM, Bottomley C et al. Incidence of epilepsy: a systematic review and meta-analysis. Neurol. 2011;77:1005-1012.

33. Johns NA et al. Cannabidiol exerts anti-convulsant effects in animal models of temporal lobe and partial seizures. Seizure. 2012;21:344352.

34. Devinsky O, Marsh E, Friedman D et al. Canabidiol in patients with treatment resistant epilepsy: an open-label interventional trial. Lancet Neurol. 2016;15:270-278.

35. Devinsky O, Cross J.H. Laux L et al. Trial of canabidiol fot drugresistant seizures in the Dravet syndrome. $N$ Engl J Med. 2017;376:2011-2020.

36. luvone T, Espisoto G, De Filippis D. et al. Cannabidiol: a promising drug for neurodegenerative disorders? CNS Neurosci Ther. 2009;15:65-75.

37. Eubanks LM, Rogers CJ, Beuscher AE et al. A molecular link between the active component of marijuana and Alzheimer disease pathology. Mol Pharm. 2006;3:773-777.

38. Bachmeier C, Beaulieu-Abdelahad D, Mullan M, Paris D. Role of the cannabinoid system in the transit of beta-amyloid across the blood-brain barrier. Mol Cell Neurosci. 2013;56:255-62.
39. Hampson AJ, Grimaldi M, Lolic M et al. Neuroprotective antioxidants from marijuana. Ann NY Acad Sci. 2000;899:274-282.

40. Casarejos MJ, Perucho J, Gomez A, Muñoz MP, Fernandez-Estevez M, Sagredo O, Fernandez Ruiz J, Guzman M, de Yebenes JG, Mena MA. Natural cannabinoids improve dopamine neurotransmission and tau and amyloid pathology in a mouse model of tauopathy. $J$ Alzheimers Dis. 2013;35(3):525-39.

41. Walter S, Mahlberg R, Eichmann U, Kunz D. $\Delta-9$ tetrahydrocannabinol for nighttime agitation in severe dementia. Psychopharmacol. 2006;185:524-528.

42. van den Elsen GA, Ahmed A, Verkes R et al. Tetrahydrocannabinol for neuropsychiatric symptoms in dementia: a randomized controlled trial. Neurol. 2015;84:2338-2346.

43. Hill KP, Palastro MD, Johnson B, Ditre JW. Cannabis and Pain: A Clinical Review. Cannabis Cannabinoid Res. 2017;2(1):96-104.

44. Kremer M. Antidepressants and gabapentinoids in neuropathic pain: mechanistic insights. Neurosci. 2016;338:183-206.

45. Whiting PF, Wolff RF, Deshpande $S$ et al. Cannabinoids for medical use: a systematic review and meta-analysis. JAMA. 2015;313:24562473.

46. Wallace MS, Marcotte TD, Umlauf A et al. Efficacy of inhaled cannabis on painful diabetic neuropathy. J Pain. 2015;16:616-628.

47. Wilsey BL, Deutsch R, Samara E et al. A preliminary evaluation of the relationship of cannabinoid blood concentrations with the analgesic response to vaporized cannabis. J Pain Res. 2016;9:587598.

48. Rocchetti M, Crescini A, Borgwardt $S$ et al. Is cannabis neurotoxic for the healthy brain? A meta-analytical review of structural brain alterations in non-psychotic users. Psychiatry Clin Neurosci. 2013;67:483-492.

49. Crean RD, Crane NA, Mason BJ. An evidence based review of acute and long-term effects of cannabis use on executive cognitive functions. J Addict Med. 2011;5:1-8.

50. Anderson GD, Chan LN. Pharmacokinetic drug interactions with tobacco, cannabinoids and smoking cessation products. Clin Pharmacokinet. 2016;55:1353-1368. 